\title{
Feminism, Conflict and Disasters in Post-tsunami Sri Lanka'
}

\author{
JENNIFER HYNDMAN
}

Social relations, including gender, are destabilized by conflict and disaster. Approaches informed by feminist thought illustrate this by probing the ways in which different identities and locations produce inequality, violence and disparate power relations. In this article, a feminist approach to development and disasters is advocated. In Sri Lanka, a country at war on and off for more than two decades, the social impact of the 2004 tsunami cannot be divorced from the pre-existing landscape with its layers of conflict, nationalism and economic disparities. This article explores the ways in which the tsunami changed people's relations of home, family and security for those who lost a spouse. Interviews with 40 widows and widowers along the east coast of Sri Lanka in February 2006 suggest that the tsunami not only reorganized gender relations among specific ethno-national groups, but also changed the meaning of 'widow' with war widows and tsunami widows positioned differently within post-tsunami society and across ethnic groups. The study shows that men with surviving young children who lost their wives view remarriage as highly desirable. The Sri Lankan government's policy of no-build buffer zones along this coast has also increased insecurity with many people still living in temporary accommodation two years after the tsunami. The prospect of remarriage for widowed women is fraught, yet more appealing as a way to mitigate insecurity than it was pre-tsunami. The author argues that a 'feminism and disaster' lens should be coupled with a 'feminism and development' approach to understanding change in the wake of the tsunami. Focusing on gender alone is insufficient.

\section{Introduction}

...disasters, however 'natural', are profoundly discriminatory. Wherever they hit, pre-existing structures and social conditions determine that

Jennifer Hyndman, Adjunct Professor of Geography, Norwegian University of Science and Technology and Professor of Geography, Syracuse University, Syracuse NY 13244, USA. Email: jhyndman@maxwell.syr.edu 
some members of the community will be less affected while others pay a higher price (Oxfam International 2005).

The devastating Indian Ocean basin tsunami of 2004 killed well over 200,000 people and displaced more than a million. In both Sri Lanka and Aceh province in Indonesia, this 'natural' disaster, however, occurred in a context of long-term conflict, displacement and 'human-made' disaster. $^{2}$ These landscapes of violence and disaster are inseparable and have rendered many survivors of the tsunami vulnerable once again due to renewed conflict in 2006. The tsunami represents one layer of displacement on top of the pre-existing political landscapes of conflict and forced migration (Nah and Bunnell 2005).

Two years after the tsunami, at the time of writing, multiple reconstruction programs, evaluations and assessments of the tsunami's impact have taken place. This study adds to the mix, addressing questions that have not received the same attention as issues of housing, livelihoods and psycho-social rehabilitation. Specifically, this study of 40 widows and widowers in Batticaloa and Akkaraipattu begins to probe changes in the everyday geographies, power structures and routines of people severely affected by the tsunami. Several of these questions were raised while I was a volunteer consultant with UNICEF in February 2005, trying to ascertain those who were rendered vulnerable by the tsunami, particularly women whose safety was at risk. ${ }^{3}$

Many similar questions were published online in Oxfam's report the following month:

How safe are women in crowded camps and settlements, when they are so outnumbered by men...? Will widows in India have access to land once owned by their husbands? Will younger women enter into marriages with much older men...? In whose names will newly built houses be registered? Will men take on new domestic roles, or will women's workload's increase? (Oxfam International 2005: 2).

The findings presented here address questions of remarriage and domestic roles where women and men lost their spouses.

War destabilizes gender and other social relations in ways that are often detrimental to women (i.e., they become more susceptible to sexual assault or prostitution) but also enabling (i.e., women in the north were 'allowed' to ride bicycles and travel alone to the market once fuel and public transit via bus in the northern parts of the country became scarce) 
(Hyndman and de Alwis 2003, 2004). As the Oxfam quote at the beginning illustrates, no disaster-whatever its antecedents-is gender neutral, just as any disaster will discriminate by class, ethnicity and other spatialized social relations. Hence, one cannot analyze gender relations separately from class, ethnicity, caste or geographical location (Hyndman and de Alwis 2003). They are co-constituted.

Joni Seager (2006) calls for social scientists, specifically geographers, to pay attention to the ways in which disasters are gendered, but is a gender analysis alone sufficient? I contend that gendered relations were shaped not only by the tsunami, but produced at the intersection of social, economic and political relations and the ongoing conflict in Sri Lanka. I have argued elsewhere that tsunami aid and post-tsunami government policies have actually contributed to nationalist tensions in Sri Lanka, especially along the east coast, the site of this study (Hyndman forthcoming).

I make the case that both academics and practitioners must go beyond 'gender and development' or 'gender and disaster' to incorporate a fully feminist lens in analyzing conditions and responses to dispossession, destruction and resulting impoverishment. A feminist lens takes gender as a major axis of difference and disparity, but not the only nor necessarily the primary one. Disasters put inequalities into stark relief. A feminist approach examines how gender differences produce material, social and other inequalities between the sexes; what other social locations (such as caste, class and ethno-national identity as illustrated below) produce inequalities; and how gendered identities, such as 'widow', intersect with others bases of identity and difference. One aim then is to probe how responses to disasters can avoid reproducing inequalities. A double analytic that includes theoretical insights from both 'feminism and development' as well as 'feminism and disaster', or FAD', is proposed.

The article begins with a brief overview of early feminist literature on 'women in development' and 'gender and development' that informs humanitarian policy and practice today (Hyndman 1998). Humanitarian, in the context of Sri Lanka, refers to programs and policies that relate to working in conflict or disaster zones where first and foremost the right to life is protected through the provision of basic necessities. Much of the aid programing in Sri Lanka goes far beyond this minimum, bleeding into full-scale development work, hence the importance of looking critically at both development and humanitarianism at the same time through this literature. 


\section{Situating the Study in Theory: WID, WAD, GAD, FAD}

Examining women's place or even gender relations in the context of humanitarian disasters is not enough (Hyndman and de Alwis 2003). Instead, the case has been made that a feminist lens is necessary to properly probe questions of development, livelihood, security and assistance in contexts where power relations were never equitably distributed. But how has development thinking in this realm morphed from a focus on 'women' to 'gender' to 'feminist'?

The institutionalization of 'women in development' (WID) in the early 1970s was largely a result of liberal feminist agitations globally. Charges that development was gender-blind or that it excluded women altogether were met with WID initiatives. Since WID, there has been 'women and development' (WAD) and 'gender and development' (GAD), but none of these necessarily focus on multiple sets of power relations and/or positionings as a starting point for change. While WID promoted integration into a masculinist (western) project of development, WAD considered inclusion into such flawed projects insufficient and advocated separate projects for women designed by them. GAD approaches were influenced by socialist feminist critiques of the modernization/development paradigm, emerging in the 1980s as an alternative to the WID and WAD approaches. Instead of focusing on women per se, the central concern of GAD approaches was the 'social construction of gender and the assignment of specific roles, responsibilities and expectations to women and to men' (Rathgeber 1990: 494). GAD started examining power relations between women and men, shifting the focus away from 'women' alone.

GAD questions the underlying assumptions of social, economic and political antecedents to uneven gender relations and 'demands a degree of commitment to structural change and power shifts that is unlikely to be found either in national or international agencies' (ibid: 495). But this commitment to structural and relational change is lost when researchers, governments or agencies simply invoke the categories of 'women' or 'gender' in an effort to include gender programing in their projects. GAD begins to probe the implications of female and male identities and examines the power relations between women and men, but by separating it out analytically from other identities and differences it does not go far enough. 
Every humanitarian project in its design, method, evaluation and impact, is gendered, just as it is embedded with culturally and politicallyspecific frames of reference. In Sri Lanka, the fact that most income generation projects for women (i.e., poultry rearing, home gardening) enable them to work from or near home carries an implicit assumption that women are inextricably linked to the private and gendered sphere of the home, often through informal work. Similarly, stereotyped roles in society are perpetuated through the training of women in particular kinds of skills and professions. For example, they are more often taught sewing and weaving - 'feminine' skills - than masonry or carpentry (Hyndman and de Alwis 2003). Instead of GAD, Hyndman and de Alwis (2003) proposed 'feminism and development' (FAD) - to include humanitarian efforts as well-as an enhanced analytical framework that incorporates multiple bases of identity and power relations, not exclusively gender. In the case of Sri Lanka, gender identity cannot be neatly separated from national identity; they are mutually constitutive. What it means to be a woman in Sri Lanka is shaped by one's religion, cultural heritage, mother tongue, caste and history in a particular location (Ruwanpura and Humphries 2004; Ruwanpura 2006). Gender relations are part and parcel of nationalist discourses (Jayawardena 1986) but also of class, caste, colonialism, religion, language ability and location (Bagwe 1998; Elliott 2005). Such a feminist approach is a more compelling position from which to transform relations that provoke or perpetuate violence, hate and inequality.

This brings me to FAD squared, or FAD. ${ }^{2}$ Just as development processes require feminist lenses to assess power relations as well as needs, resources and logistics (feminism and development), so do disasters, hence feminism and disasters (FAD). In Sri Lanka, 'Struggles over interethnic justice, neo-liberalism, economic distribution, the disempowerment of women, caste bigotry and such have shaped the [Sri] Lankan political landscape in significant ways over the last decades... even the tsunami cannot wipe out the imprint of these fault lines' (Nesiah, Nanthikesan and Kadirgamar 2005). I pluralize 'disasters' purposefully to underscore the intersection of conflict and natural disaster in the context of Sri Lanka.

The use of feminist thinking is also deliberate. To assume that gender is somehow the primary category of analysis or most disparate axis of difference within a context of neoliberal imperatives, competing nationalisms 
and other prejudices is too simplistic. As Chandra Mohanty (2003) has argued, the category 'woman' is inherently unstable. Its meaning also varies across ethno-national identity and geographic location. Gender cannot be analyzed in isolation from these co-constitutive factors. Ultimately, these differences intersect in ways that position people very specifically in relation to each other. While GAD does commit to structural and relational change where necessary, this approach assumes that the change will need to be made in relation to gender. Caste bigotry, ethno-national differences and the economic geographies of displacement due to war are not accounted for. For example, the areas of Sri Lanka most affected by war in the east are also the areas most adversely affected by the tsunami. The Eastern Province is disproportionately populated by two minority ethnic groups, Tamils and Muslims. The empirical section of this article, then, aims to show that the very meaning of 'widow' is unstable in the context of ethno-national identity, war and disaster.

This brings me to a brief outline of Sri Lanka's recent political history to illustrate some of the tensions that transcend but include gender.

\section{Situating Sri Lanka}

The 24-year-old war in Sri Lanka has been characterized as one of violent competing nationalisms between the Liberation Tigers of Tamil Eelam (LTTE) and the government of Sri Lanka's armed forces since the pogroms of 1983 (Jayawardena and de Alwis 1996). Sri Lanka's present is an expression of a long history and geography of struggle well documented by Sri Lankan and Sri Lankanist scholars (Abeysekera and Gunasinghe 1987; Jeganathan and Ismail 1995; Spencer 1990; Thiruchelvam 1996). The conflict has spawned large-scale displacement within the country and well beyond its borders, where a significant Sri Lankan Tamil diaspora has emerged from this country of just under 20 million people (Daniel 1997; Fuglerud 1999; Hensman 1993). The death toll as a result of the conflict exceeds 65,000 people.

A ceasefire was signed in February 2002. This was held during the tsunami and until 2006, despite the escalation of ceasefire violations in 2004 and political assassinations in 2005. The ceasefire began to dissolve in the middle of 2006, when a suicide bomb attack in Colombo sparked what has been an ongoing conflict ever since. More than 1,000 people 
were killed in 2006, including an unprecedented attack on 17 staff working for an international relief organization who were murdered en masse in August (Apps 2006). In February 2007, the attempted assassinations in Batticaloa of the ambassadors of America and Italy, allegedly by the LTTE, signalled an escalation in the conflict.

In 2006-07, renewed conflict also forced thousands of Tamils, including many tsunami survivors in the Eastern Province to flee homes and temporary shelters for the second time in two years (Pathoni 2006). Compared to reconstruction in the Sri Lankan south, which is almost complete, much of eastern Sri Lanka has been shaken by renewed conflict after being shattered by the tsunami in December 2004. In January 2005, however, it was the government's buffer zone policy that made housing reconstruction difficult, not the war.

\section{The Tsunami and the Implementation of Buffer Zones}

In January 2005, when the buffer zone made its entrance after the waves had left behind the destruction, it was known by another, less popular name- the set back zone. It most certainly has lived up to that title (Perera 2005).

After the tsunami, the Sri Lankan government legislated buffer zones ostensibly as a public safety measure against the potential devastation of another tsunami (CPA 2005; Jansz 2005). The buffer zones are important to this discussion because they created yet another layer of displacement on top of those created by conflict and the tsunami. On a longer-term basis, the buffer zone edict has spatially rearranged neighbors and villages, transformed commuting times to school and employment and created uncertainty for those who lost homes inside the buffer zones and whose temporary shelters are becoming increasingly permanent.

In the densely populated south, dominated by a Sinhala majority and international tourism, a one hundred-meter buffer zone was established. In the Tamil- and Muslim-dominated Eastern Province, where tsunamirelated devastation and damage had proved to be the greatest, a two hundred-meter buffer zone was declared. In both areas, the high population density and land scarcity made the unequal set-backs highly contentious (Hyndman forthcoming). This government policy was significant in two ways. First, it meant that those displaced from their homes inland 
to the coast, were then displaced, if not killed, by the tsunami, and then again displaced from the coast if they lived within the designated buffer zones. Second, the no-build buffer zone in the east, where minority groups in Sri Lanka's fraught political history are over-represented, was twice as large as that in the south, dominated by the majority Sinhala who back the government, resulting in a strong feeling of prejudice and resentment on the part of minority Tamils and Muslims. The buffer zones effectively displaced yet again those who had lost their homes close to the sea in the tsunami, rearranging home life, commutes to school, travel to markets and access to livelihoods. This new geography of post-tsunami resettlement has reshaped social relations and family life.

The intention of these 'no-build' areas was to move people's residences away from the coast in an effort to prevent future deaths should another tsunami occur. As the Institute for Policy Studies (2005) in Colombo stated, if public safety was the prevailing aim, the buffer zones should have been equal for all areas. The specific environmental, social and physical characteristics of coastlines in different parts of the country ostensibly require responses tailored to those geographies, but none was forthcoming. Instead, Sri Lanka's World Bank representative, Peter Harrold, noted that buffer zones have been the single greatest barrier to progress in housing reconstruction for those who lost their homes in the tsunami (cited in Dias 2006).

The buffer zones also generated insecurity for those who lost their homes inside the zones. These people, including those along the east coast interviewed for this study, now live in temporary shelters at locations different from their original homes. The many Tamil and Muslim villages scattered along the coast in the Eastern Province were ethnically homogenous to a significant extent before the tsunami. These precarious political geographies, born largely as a reaction to mistrust and the conflict, have been undone by the tsunami and the policy of buffer zones. New livelihoods have been re-established in temporary communities until land can be identified for more permanent housing (CPA 2005). Before addressing insecurity in these temporary shelters and the implications for widows and widowers, I briefly review the analyses of why so many more women than men died in the tsunami. After establishing the socially produced conditions that differentiated the tsunami's impact and the difference that ethnicity makes in this context, I present my own findings. 


\section{Post-tsunami Change in Sri Lanka: Why did So Many Women Die?}

After the tsunami, Oxfam International (2005) conducted a multi-country study that reported that women were up to three times more likely to have died than men. The same ratio was reported by another source in Sri Lanka, where more than three times as many women than men died in the 16 to 30 years old age group, leading experts to fear that the tsunami could have long term detrimental effects on birth rates in tsunami affected regions (Sri Lankan Government and Development Partners 2005).

Sarala Emmanuel (2005) conducted a post-tsunami study of 200 households in Batticaloa which examined housing, livelihoods, human loss and related issues identified by the people interviewed. From her sample, which was predominantly Tamil ( 93 percent), she found that 80 percent of the people who died in the tsunami were women. Not only were female lives lost but women's wealth, often in the form of gold jewellery (but also bicycles), was also swept away by the destructive waves.

Certainly women were killed in greater numbers than men, an observation that is as much socially produced through caregiver roles, socialization as children and gendered clothing norms than any physical differences in strength. The skill sets of women and men are, for example, highly gendered. Shanthi Sivasanan, a Programme Assistant with Oxfam, observed that many men climbed trees to escape the water. This was something they had done many times before to pick fruit and while playing. But women had never climbed trees before, and so could not when they needed to (Oxfam International 2005).

In their study of the tsunami's impact on women in Batticaloa and Hikkaduwa de Mel and Ruwanpura (2006) suggest that one reason so many women were killed was that many villages hold markets called polas on Sundays, the day the tsunami hit. These markets, or fairs, are generally located on the main coastal roads, not far from the seaside, where mostly women buy and sell their produce. So, women's labor positioned them in spaces of vulnerability in relation to the tsunami, i.e., marketing, washing pots and pans and looking out for their children's safety. One woman recounted the day the tsunami hit and how her clothing choice increased her mobility in relation to other women:

I was at the fair when the waves came... When I saw the wave I ran back, passed the railway tracks and went to the station. I was wearing 
a maternity frock. I heard that women who were wearing tight skirts got caught in the wave and died as it was difficult for them to run (Manel, a 26-year-old woman from Seenigama cited in de Mel and Ruwanpura 2006: 21).

Manel goes on to testify that she and others mistook the tsunami for a rebel attack:

On the day the tsunami happened I was at the Sunday fair. People were crying that the LTTE was attacking. The noise of the wave crashing against the shops and buildings must have been so loud that everyone thought the Tigers were bombing the area. I thought I lost my child and my mother-in-law in the bombing (cited in de Mel and Ruwanpura 2006: 24).

The intersection of conflict with the devastation of the tsunami creates intense security problems for certain segments of Sri Lankan society, particularly unmarried women. One teenage girl explained the conundrum in which she finds herself:

We are still living in a camp. My parents are trying to marry me off to a man who is 15 years older. They say they can't protect me, or give me dowry. I want to go back to school, study and then get a job (a girl, Mutur, Women and Media Collective 2005).

Having briefly traced the spaces that the women occupied when the tsunami struck, their caregiver roles and gender-specific comportment, I now elaborate first on the unstable meaning of 'widow' in eastern Sri Lanka given the differences that ethnicity makes, and second on the insecurities that both the widows and widowers face since the tsunami.

\section{Destabilizing the Categories 'Women' and 'Widow': Gender Meets Ethnicity}

Gill Valentine (2007) analyzes intersectionality in feminist scholarship, arguing that not only are identities co-constituted across multiple axes of difference (including but not limited to gender), but also that different identities may come to the fore as primary at different times. Valentine uses the metaphor of 'geometries of oppression' to trace how identity is 
'done', by whom, and when. 'The identity of particular spaces-the home, the school, the workplace, or a community space such as a deaf clubare in turn produced and stabilized through the repetition of the intersectional identities of the dominant groups that occupy them' (Valentine 2007: 19), yet the foregrounding of particular identities can vary across a single lifetime.

With respect to Sri Lankan widows, for example, Ruwanpura and Humphries (2004:187) posit that a young widow with children is likely to face greater financial responsibilities than an older one with grown children: 'The needs of a young widow with several dependent children whose husband has been killed in ethnic violence may be very different from the needs of a middle-aged widow with several children old enough to work....' Further, widows are caste as more deserving female heads of households than their non-widow counterparts. These authors question homogenizing accounts of Sri Lankan women's lives and explore ethnicity as a source that produces differences among woman-headed households in eastern Sri Lanka.

Ruwanpura and Humphries (2004: 179) document significant differences across female-headed households despite 'oppressive gender standards within both Sinhala and Tamil ethnic groups... emphasizing motherhood and sacrifice as the archetypal feminine path....' Malathi de Alwis (1998) has written extensively about 'moral motherhood' in the context of the war in Sri Lanka and the ways in which women are used in nationalist projects as reproducers of the nation and bearers of cultural identity. Gender and ethnicity, then, co-constitute and differentiate the meaning of 'woman', and by definition 'widow', in Sri Lanka.

Ruwanpura and Humphries (2004) also analyze factors that precipitate and inhibit the formation of woman-headed household, exposing significant differences among Tamil, Muslim and Sinhala women, both widows and non-widows. ${ }^{4}$ Where Sinhala women head of households stand to benefit from the Sinhalese legal code (including matrilineal property inheritance laws) and relaxed social status due to their majority ethnic group status, Muslim women are hampered by restrictions on their mobility and related obstacles to income-earning opportunities. Distinct patterns of employment among Muslim, Tamil and Sinhala women heads of households were noted, with 59.4 percent of Sinhala women participating in wage labor, compared to 17.2 percent for Tamil women and 31 percent for Muslim women with the same household configuration. 
Likewise, Sinhala women who were heads of household were less likely to be self-employed (23.3 percent) than either Tamil women ( 46.6 percent) or Muslim women (41.6 percent) in the Eastern Province where the study was conducted. The intersection of gender, ethnicity and relations of paid work varied significantly across the various permutations of identity.

More specifically, the 'rate' of widowhood in the three districts surveyed well before the tsunami varied significantly by ethno-national identity. Whereas 52.2 percent of Sinhala women heads interviewed were widows, 67.2 percent of Tamil women and 61 percent of Muslim women heads were widows. ${ }^{5}$ How these women were widowed was also probed in the study, revealing that 28 percent of Sinhala widows' husbands were killed (as opposed to dying of natural causes or disease) compared to 22 percent for Muslim women in the same position and 72 percent for Tamil women (Ruwanpura and Humphries 2004). These differences are startling and point to the differential effect of the conflict on households, as this study was conducted before the tsunami. In post-tsunami Sri Lanka, these figures have changed, as has the very meaning of 'widow.'

\section{War Widows and Tsunami Widows: Possibility and Fear}

Before the tsunami, the conflict produced a number of widows on all sides of the war. Normally, widows who live without the protection of their extended family are harassed; their movements are judged suspiciously and their reputations are always at stake. Prospects for subsequent marriages are slim (Bagwe 1998). The despair of one woman who was widowed by the conflict after the tsunami captures her precarious social and personal positioning: 'I had hope and happiness when my husband was alive. Now I have no hope. I have only fear and sadness. It's affecting my mind. [I'm] scared to keep my son.... What a life! [I] have to live in eternal fear.' Societal interventions to change public attitudes and ridicule are necessary, as Deepa Mehta's 2005 film, Water, compellingly illustrated, but the general insecurity of widows living on their own and of single women has been a pressing issue for some time (de Alwis and Hyndman 2002).

The tsunami wiped out a whole set of social relations for some women who lost not only their spouses but their own extended families and that of their dead husbands. Where they exist, these familial networks 
normally provide material support, social respectability and security for widows. In their absence, social authority is destabilized. Said one woman, a 25-year-old widow who lost her husband and three children in the tsunami: 'Before the tsunami I had my husband's protection. Now I live with my old mother. Brothers are not living near. So there is no protection.'

Security is highly geographical, based on the proximity of male relatives. Yet it is also social. As several widowers explained of the women who lost their spouses in the tsunami:

The [women] widowed due to the tsunami did not have anyone. No children, siblings or parents. They didn't have any protection or help. So they remarried to get some kind of comfort. Widows of war did not lose all their relatives; so they did not want to remarry (a 21-yearold widower with no children).

From this male perspective, a woman who is widowed is without protection. Security is secured through social relations, especially marriage:

...If a widow speaks to a man immediately they [the men] spread stories. This is why marriage takes place. There is no help for tsunami widows. No one to guide them. So if they decide, they remarry. During war, widows did not lose [all] their relatives. So they did not have any interest in remarrying (a 30-year-old widower with two small children).

This respondent explains that remarriage is a widow's choice, but is it a choice if she is without protection and perhaps material support and at risk of losing her reputation? As a 28-year-old woman who lost her husband, mother, two elder sisters and a niece in the tsunami lamenting the loneliness she experiences observed: 'I live alone.... Housework has reduced.... Now loneliness is biggest torture.' She notes that she would need US $\$ 2,000$ as dowry to remarry and while she is unsure she wants to marry again, remarriage is not simply her 'choice'. A third man who lost his wife echoes this idea that women choose, but also makes the key distinction between 'war widows' and 'tsunami widows'.

The widows of tsunami lost everything in one day. They lost their relatives and have no protection or support. There is no one to comfort or to tell what is good or bad. Therefore they have remarried immediately. The final decision to remarry lies in their hands alone. But 
war widows had the support of their relations (a 42-year-old widower, who lost two children and has one surviving daughter).

From these men's points of view, remarriage is purely practical, a necessity in the face of insecurity. They do not question why women are unprotected if they are outside marriage, nor suggest alternatives beyond marriage.

Women's own views on remarriage, at least of those widows interviewed in this study, are distinct from the men's and complicated by concerns for their children's well being. A 34-year-old widow with five surviving children said:

Women will not remarry. The man will definitely torture her children. Even during the war when women became widows they did not remarry. My husband was very loving. I will not remarry. I think my trouble will be over when my eldest son completes his studies.

She observes that she will eventually have protection through her son, once he is old enough and has completed school. More importantly, the risk of having one's children mistreated by a new spouse seems to be a very vivid fear for more than just this woman. A 40-year-old widow interviewed also used the word 'torture': 'No woman known to me has remarried. The reason for this is that the new husband might torture the surviving children.' Three more echo this sentiment:

Most men have remarried. Very few women have married. Most of the men (except 3) have got married to young women. I feel that people with children should not remarry. They'll be step parents and children will get affected by this (a 37-year-old widow with two surviving children, 10 and 7 years, emphasis added).

I'm not interested in remarriage. There'll be problems (a 25-yearold woman who lost her husband and three children).

Very few women have remarried. Men normally get [re]married. About 10 marriages took place this week (5/02/06). So many marriages have taken place within the first month of tsunami. Most men have married young women. Women are the ones who died more in the tsunami, so more widowers than widows (a 45-year-old woman who lost her two daughters, husband and grandchildren, and has one surviving son, who is sick). 
Very clear concerns about the treatment of children by new spouses are reiterated here. The observation that widowers are more likely to marry younger (i.e., unmarried) women where possible is also noted by two women. The families of younger, not-yet-married women, who lost all their assets in the tsunami are more likely to be able to provide dowry for the daughter, making her more 'marriageable.'

As one 49-year-old widow, stated: 'Very few women [get married]. But more men have married. Fear is the main reason for women. Also who has the ability to give dowry and get married? Men go outside their families and get married.' Women's 'choice', where dowry is expected, is less about independent decisions and more about societal expectations that may have changed since the tsunami, but cannot be ignored altogether. Fear is also a driving force.

Many of the widowers we interviewed wanted to remarry; they see marriage as highly practical but no doubt seated in culturally-based norms. The idea that the tsunami reorganized the gender division of labor, especially unpaid labor of childcare in the home, has been short-lived. Some of the men we interviewed did recognize childcare as hard work:

The six months I spent looking after my children is the most difficult time. I don't know how women do all this work. I had to really struggle (a 39-year-old widower with three surviving children, now remarried to a mother of two children).

I am happy from the time I got [re]married. My new wife looks after me and my children the same way my first wife did. She washes my children's clothes. She protects us... (a 38-year-old widower, with three surviving children who remarried a 35-year-old war widow with two children).

I have a son aged two-and-a-half years. There is no one to look after him... all what Chandra [his dead wife] did is done by me now. When I go to work I take him along to the work place.... I have plans to remarry.... You need another person's help isn't it? (a 48-yearold widower).

Two of these men are happily remarried and point to the unpaid domestic work that their new wives do for them. The third plans on marrying, for the help a new wife would provide. A slightly older man who lost his wife and has three older children is more reluctant to remarry: 'A man or 
woman with a small child has to get married... [but] I think whoever gets married and comes won't look after my children like their own children' (a 42-year-old widower with two adult sons and a 12-year-old daughter). He will not remarry; he has to focus on marrying off his kids. Like the women quoted above, he doesn't believe that his new spouse will necessarily treat his children properly.

Another man spoke of the strife his plans for remarriage have caused. None of his family supports this decision:

I have not remarried yet. I have spoken about it. She is a widow aged 35 years with two children. My sister-in-laws don't like the idea of me getting married to her. But I have decided. I am remarrying because I want my life to return to what it was like before. I need someone to cook and wash for me.... No one talks to me since I decided to get [re]married (my mother, my sisters-in-law).... Now I live a lonely life (a 39-year-old father with a 13-year-old girl).

Given the testimony of two women and one man about 'torture' given above, it could be the well-being of the teenaged girl that concerns the extended family, although one cannot know this from the transcripts. In any case remarriage for men appears to be a less fraught process than for women. Yet, the absence of protection or security, socially speaking, appears to be a major consideration for widows or single women who find themselves without the presence of extended families. When asked about their security, men interpreted the questions we asked quite differently:

[We have] no protection. Earlier when we went to work, we did not have any problems on the way. No army or police checking. Now when we say we are from Thirai madu they think we are with the terrorists. Because of this there are more problems. We have to show proof with our identity cards. Once when they rounded us up, they made us kneel (a 21-year-old widower).

...there is more fear for safety now (a 28-year-old widower).

There is no protection for our life (a 48-year-old widower).

In these excerpts from the transcripts pertaining to security, all refer to physical safety and the rise of insecurity in relation to daily mobility, not social insecurity. Security itself is a highly gendered construct in the context of conflict and disaster. Where the loss of family relations during 
the tsunami and gender identity intersect, widows find themselves in new situations of vulnerability. Just as 'women' is a precarious term given its various referents across ethnicity, 'widow' is also an unstable category that has been changed by the tsunami.

So where does this leave us with regard to intersectionality (the coconstitutive relationship of various identities and differences with one another) and the earlier proposal of feminism and development/feminism and disasters, or FAD'? Feminism, the 'f' word, can make development practitioners, NGO staff, humanitarian workers and UN officers nervous. But its meanings here are hardly controversial. I employ the term 'feminist' here in a broad sense to describe analyses and interventions that address the multiple differences and locations that generate inequalities and even violent relationships among people and places, including but not limited to gender relations. Feminism and development/feminism and disasters $\left(\mathrm{FAD}^{2}\right)$ are about deepening one's analysis beyond gender and seeing the conflict and the tsunami as co-constitutive of women's security and both women's and men's decisions to remarry.

\section{Without Conclusion}

This article has shown how 'widow' and 'women' are unstable categories in the context of war and tsunami. Both vary by ethnicity and by the kind of disaster that may have precipitated it (i.e., conflict versus tsunami). Gender and ethnic identities co-constitute the meaning of widow, but location in the conflict zone and tsunami-affected areas also define one's sense of self and security in a war zone. The meaning of widow is itself highly spatialized, shaped by displacement through landscapes of conflict for almost 25 years, of the tsunami since 2004 and of dislocation vis-àvis the government's buffer zone policy since 2005 .

Class, race, caste, sexuality, religion, nationality and ethnicity are all potential bases for exclusion, discrimination and even violence. As Gill Valentine (2007) argues, these strands of history and geography are not additive or separable from one another. Rather, a feminist approach that draws on intersectionality, like $\mathrm{FAD}^{2}$, extends and improves upon prevailing approaches to gender programing in non-governmental organizations, $\mathrm{UN}$ agencies and donor circles. As an academic or a practitioner, one must focus not only on the differences between women and men after the tsunami, but on the differences within the category 'woman' and 'widow' 
as well. A 'gender analysis' alone is insufficient. The practices of aid, policy and history which position certain groups of people in hierarchical relation to others are not easily unravelled, but this is the work that feminism and development coupled with feminism and disaster, $\mathrm{FAD}^{2}$, can do. The well-intentioned work of development workers and humanitarian actors can unwittingly reproduce and perpetuate existing gender, racial and geographical hierarchies by uncritically promoting certain kinds of projects i.e., sewing for poor, conflict-affected women (de Alwis and Hyndman 2002).

In relation to this study, my aim has been modest: I have probed the tsunami's impact on the meaning of 'widow', the spaces and predicaments that widowers and widows occupy in post-tsunami Sri Lanka and the ways in which households have been reconfigured. I imagined that the study might find some male-headed households with fathers cooking, cleaning and looking after their children. An Oxfam officer in Akkaraipattu told me she knew of two men who were doing this work in February 2006, some 14 months after the tsunami.

Yet, the gender division of labor has not changed significantly. Women's workloads in some extended households have increased, but there is just as much preliminary evidence to suggest that women widowed by the tsunami have witnessed their workloads decrease, especially among those who lost children.

The men we interviewed in Batticaloa and Akkaraipattu distinguish between 'war widows' and 'tsunami widows', with the latter having less family protection and therefore more proclivity, in their minds, to remarry. They see remarriage as a decision or choice that the women make, despite the testimony from five women that they would not consider remarriage because it could be detrimental to their children's welfare. Dowry also represents a major obstacle that widows face if they do, in fact, desire to remarry. For widowers with small children, in contrast, remarriage is seen as a necessity, as it is expected that a woman is needed to care for children, wash the family's clothes and cook for the family in the long term.

With respect to two of the questions Oxfam posed in its March 2005 assessment of the tsunami: 'Will younger women enter into marriages with much older men...? Will men take on new domestic roles, or will women's workloads increase?' (Oxfam International 2005: 2), the answers appear, at least provisionally, to be yes, men are more likely to marry younger, unmarried women, though several have remarried widows of 
the tsunami and of war; the demographic implications of this shift in marriage patterns for younger unmarried men remains to be seen. And finally, men have not taken on new domestic roles permanently.

On a more hopeful note, this study raises many more questions for further research. As de Mel and Ruwanpura (2006: 18) note, 'Sri Lanka's property rights regime has been upheld as a feminist haven for its bilateral and matrilineal inheritance patterns through customary and codified law.' Most of the people we interviewed told similar stories: land titles were in the names of wives and daughters, though none had a new home yet due to the buffer zone policy. Given that a majority of the new permanent homes have yet to be built (CPA 2005), research on this issue will be needed once they have been built. Did women lose ground on property ownership, and if so, who and why? Are there any patterns that suggest those of a specific ethno-national group, class, location and/or gender lost out? Much more feminist research on disasters and the development work that follows needs to be done.

\section{NOTES}

1. The author would like to thank Sue Wadley, the editors and two anonymous referees for their comments on earlier drafts of the manuscript, as well as Rebecca Mark for her invitation to present an earlier version of this work at the 'Educating Women for a World in Crisis', Conference at the Newcomb College Institute, Tulane University, New Orleans in February 2007.

2. This is true of Burma/Myanmar as well, although the government of this country refused to acknowledge the tsunami and the damage that it caused. Since 1988, the country has been ruled by a military junta, which refuses to accept its defeat in a 1990 election.

3. I worked with Mala de Alwis on this UNICEF consultancy; this study would not have been possible without her inspiration and assistance.

4. The authors base their analysis on 298 interviews with women-headed households in the Trincomalee, Batticaloa and Amparai districts of eastern Sri Lanka.

5. The authors note that the sample is not technically representative of all female-headed households but its size (298 interviews) suggests strong correlations nonetheless.

\section{REFERENCES}

Abeysekera, Charles and Gunasinghe, Newton. (eds) (1987) Facets of Ethnicity in Sri Lanka, Social Scientists' Association, Colombo.

Apps, Peter. (2006) 'Shelling a call to war, Tamil rebels say,' The Globe and Mail, 7 August. Bagwe, Anjali. (1998) Of Woman Caste, Zed Books, London. 
Centre for Policy Alternatives (CPA). (2005) 'Landlessness and Land Rights in PostTsunami Sri Lanka,' Centre for Policy Alternatives Research Paper commissioned by International Federation of the Red Cross, Colombo. 16 November, available at: http://www.cpalanka.org/research papers/IFRC land study.pdf (Accessed on 10 October 2007).

Daniel, Valentine. (1997) 'Suffering Nation and Alienation,' in Kleinman Arthur, Das Veena and Lock Margaret (eds), Social Suffering, University of California Press, Berkeley, pp. 309-58.

de Alwis, Malathi. (1998) 'Moral Mothers and Stalwart Sons,' in Ann Lorentzen Lois and Turpin Jennifer (eds), Women and War Reader, New York University Press, New York, pp. 254-71.

de Alwis, Malathi and Hyndman, Jennifer. (2002) Capacity-building in Conflict Zones: A Feminist Analysis of Humanitarian Assistance in Sri Lanka, International Centre for Ethnic Studies, Colombo.

de Mel, Neloufer and Ruwanpura, Kanchana, N. (2006) 'Gendering the Tsunami: A Report of Women's Experiences from Sri Lanka,' International Centre for Ethnic Studies, Colombo.

The Economist. (2005) Relief but little rebuilding. The Economist 24 December.

Elliott, Carolyn, M. (2005) 'Introduction,' in Gulati Leela and Bagchi Jasodhara (eds), A Space of Her Own, Sage Publications, New Delhi/Thousand Oaks/London, pp. 9-19.

Emmanuel, Sarala. (2005) 'Contextualizing Post-Tsunami Challengers: Research Findings of Household Survey in Tsunami Affected Areas,' in Proceedings of South Asian Conference on Gender Concerns in Post-Tsunami Reconstruction, Suriya Women's Development Centre, Batticaloa, Sri Lanka, 15-16 July.

Fuglerud, Oivind. (1999) Life on the Outside: The Tamil Diaspora and Long Distance Nationalism, Pluto Press, London.

Hensman, Rohini. (1993) Journey Without a Destination, Centre for Society and Religion, Colombo.

Hyndman, Jennifer. (1998) 'Managing Difference: Gender and Culture in Humanitarian Emergencies,' Gender, Place, and Culture 5 (3): 241-60.

. (forthcoming) 'The Securitization of Fear in Post-tsunami Sri Lanka,' Annals of the Association of American Geographers.

Hyndman, Jennifer and de Alwis, Mala. (2003) 'Beyond Gender: Towards A Feminist Analysis of Humanitarianism and Development in Sri Lanka,' Women's Studies Quarterly 31 (3-4): 212-26.

. (2004) 'Bodies, Shrines, and Roads: Violence, (Im)mobility, and Displacement in Sri Lanka,' Gender, Place and Culture 11 (4): 535-57.

Jansz, Frederica. (2005) 'Using the Tsunami to Muzzle the People,' Sunday Leader, 20 February.

Jayawardena, K. (1986) Feminism and Nationalism in the Third World, Zed, London.

Jayawardena, Kumari and de Alwis, Malathi. (1996) 'Introduction,' in Jayawardena Kumari and de Alwis Malathi (eds), Embodied Violence: Communalising Women's Sexuality in South Asia, Kali for Women, New Delhi, pp. ix-xxii.

Jeganathan, Pradeep and Ismail, Qadri. (eds) (1995) Unmaking the Nation: The Politics of Identity and History in Modern Sri Lanka, Social Scientists' Association, Colombo. 
Mohanty, Chandra Talpade. (2003) 'Under Western Eyes: Feminist Scholarship and Colonial Discourse,' in Feminism Without Borders: Decolonizing Theory, Practicing Solidarity, Duke University Press, Durham, NC and London, pp. 17-42.

Nah, Alice M. and Bunnell, Tim. (2005) 'Ripples of Hope: Acehnese Refugees in Posttsunami Malaysia,' Singapore Journal of Tropical Geography 26 (2): 249-56.

Nesiah, Vasuki, Nanthikesan, S. and Kadirgamar, Ahilan. (2005) 'Post-tsunami Reconstruction-new challenges, new directions,' Lines, e-journal 3 (4) available at: http:// www.lines-magazine.org/tsunami/linestsunamivision.htm (Accessed on 2 June 2005).

Oxfam International. (2005) 'The Tsunami's Impact on Women,' Oxfam Briefing Note, March, available at: www.oxfam.org.uk/what we do/issues/conflict disasters/ downloads/bn tsunami women.pdf (Accessed on 16 December 2006).

Pathoni, Ahmad. (2006) 'Still Shaking, Asia Marks Tsunami', The Globe and Mail, 27 December.

Perera, Amantha. (2005) 'The Buffer Zone Fiasco'’ The Sunday Leader, 25 December, p. 16.

Rathgeber, Eva. (1990). 'WID, WAD, GAD: Trends in Research and Practice,' Journal of Developing Areas 24(4): 489-502.

Ruwanpura, Kanchana. (2006) 'Conflict and Survival: Sinhala Female-Headship in Eastern Sri Lanka,' Asian Population Studies 2 (2): 187-200.

Ruwanpura, Kanchana and Humphries, Jane. (2004) 'Mundane Heroines: Conflict, Ethnicity, Gender and Female Headship in Eastern Sri Lanka,' Feminist Economics 10 (2): 173-205.

Seager, Joni. (2006) 'Editorial: Noticing Gender (or not) in Disasters,' Geoforum 37: 2-3.

Spencer, Jonathan. (ed.) (1990) Sri Lanka: History and the Roots of Conflict, Routledge, London/New York.

Sri Lankan Government and Development Partners. (2005) 'Post tsunami Recovery and Reconstruction,' Joint Report, Colombo (December).

Thiruchelvam, Neelan. (1996) 'Sri Lanka's Ethnic Conflict and Preventive Action: The Role of NGOs,' in R. Rotberg (ed.), Vigilance and Vengeance: NGOs Preventing Ethnic Conflict in Divided Societies, Brookings Institution, Washington DC, pp. 147-64.

Valentine, Gill. (2007) 'Theorizing and Researching Intersectionality: A Challenge for Feminist Geography,' The Professional Geographer 59 (1): 10-21.

Women and Media Collective. (2005) 'One Year After the Tsunami!,' advert with INFORM and Coalition of Tsunami Affected Women, Daily Mirror, 26 December. 